\title{
Olivibacter soli sp. nov., Olivibacter ginsengisoli sp. nov. and Olivibacter terrae sp. nov., from soil of a ginseng field and compost in South Korea
}

\author{
Correspondence \\ Wan-Taek Im \\ wandra@kaist.ac.kr \\ Sung-Taik Lee \\ e_stlee@kaist.ac.kr
}

\author{
Liang Wang, ${ }^{1,2}$ Leonid N. Ten, ${ }^{3}$ Hyung-Gwan Lee, ${ }^{2}$ Wan-Taek Im $^{2}$ \\ and Sung-Taik Lee ${ }^{2}$ \\ ${ }^{1}$ College of Bio and Food Technology, Dalian Polytechnic University, Qinggong-yuan No.1, \\ Ganjingzi-qu, Dalian 116034, People's Republic of China
}
${ }^{2}$ Department of Biological Sciences, Korea Advanced Institute of Science and Technology, 373-1, Guseong-dong, Yuseong-gu, Daejeon 305-701, Republic of Korea
${ }^{3}$ Department of Biology and Medicinal Science, Pai Chai University, 14 Yonja-1st Street, Seo-Gu, Daejeon 302-735, Republic of Korea

The genus Olivibacter of the family Sphingobacteriaceae was proposed by Ntougias et al. (2007), and, at the time of writing, comprises just one species, Olivibacter sitiensis. In this study, we report on the taxonomic characterization of three Olivibacter-like bacterial strains, Gsoil $034^{\mathrm{T}}$, Gsoil $060^{\mathrm{T}}$ and Jip $13^{\mathrm{T}}$.

Strains Gsoil $034^{\mathrm{T}}$ and Gsoil $060^{\mathrm{T}}$ were isolated from soil from a ginseng field in Pocheon Province, South Korea. The soil sample was thoroughly suspended in $50 \mathrm{mM}$ phosphate buffer ( $\mathrm{pH} 7.0$ ), serially diluted in the same buffer and then spread on one-fifth-strength modified R2A plates containing the following $\left(\mathrm{l}^{-1}\right): 0.25 \mathrm{~g}$ tryptone, $0.25 \mathrm{~g}$ peptone, $0.25 \mathrm{~g}$ yeast extract, $0.125 \mathrm{~g}$ malt extract, $0.125 \mathrm{~g}$ beef extract, $0.25 \mathrm{~g}$ Casamino acids, $0.25 \mathrm{~g}$ soytone,

The GenBank/EMBL/DDBJ accession numbers for the 16S rRNA gene sequences of strains Jip $13^{\top}$, Gsoil $034^{\top}$ and Gsoil $060^{\top}$ are AB267714, AB267715 and AB267716, respectively.
$0.5 \mathrm{~g}$ glucose, $0.3 \mathrm{~g}$ soluble starch, $0.2 \mathrm{~g}$ xylan, $0.3 \mathrm{~g}$ sodium pyruvate, $0.3 \mathrm{~g} \mathrm{~K}_{2} \mathrm{HPO}_{4}, 0.05 \mathrm{~g} \mathrm{MgSO}_{4}, 0.05 \mathrm{~g}$ $\mathrm{CaCl}_{2}$ and $15 \mathrm{~g}$ agar. The plates were incubated at $30{ }^{\circ} \mathrm{C}$ for 1 month. Single colonies on the plates were purified by transferring them onto new plates for incubation once again on full-strength modified R2A or on one-halfstrength modified R2A. Strain Jip $13^{\mathrm{T}}$ was originally isolated from compost, composed of cow dung and rice straw, collected in Chungwon Province, South Korea. The compost sample was thoroughly suspended in $50 \mathrm{mM}$ phosphate buffer ( $\mathrm{pH} 7.0$ ), serially diluted and then spread onto R2A agar (Difco) plates. The plates were incubated at $30{ }^{\circ} \mathrm{C}$ for 3 weeks. Single colonies on the plates were purified by transferring them onto new plates. The purified colonies were tentatively identified using partial sequences of the 16S rRNA genes (Im et al., 2003, 2005). As strains Gsoil $034^{\mathrm{T}}$, Gsoil $060^{\mathrm{T}}$ and Jip $13^{\mathrm{T}}$ could grow well both on full-strength modified R2A agar and on commercial R2A 
agar (Difco), they were routinely cultured on R2A agar at $30{ }^{\circ} \mathrm{C}$ and maintained as glycerol suspensions $(20 \%$, w/v) at $-70{ }^{\circ} \mathrm{C}$.

Extraction of genomic DNA was done using a commercial genomic DNA extraction kit (Core Biosystem). The 16S rRNA genes were amplified from the chromosomal DNA using the universal bacterial primer set $9 \mathrm{~F}$ and $1512 \mathrm{R}$; the purified PCR products were sequenced by Solgent Co. Ltd (Daejeon, Republic of Korea) (Kim et al., 2005). Full sequences of the 16S rRNA genes were compiled using SeqMan software (DNASTAR). The 16S rRNA gene sequences of related taxa were obtained from GenBank. Multiple alignments were performed using the CLUSTAL_X program (Thompson et al., 1997). Gaps were edited in the BioEdit program (Hall, 1999). Evolutionary distances were calculated using Kimura's two-parameter model (Kimura, 1983). Phylogenetic trees were constructed using a neighbour-joining method (Saitou \& Nei, 1987) and maximum-parsimony (Fitch, 1971) with the MEGA3 program (Kumar et al., 2004); bootstrap percentages were calculated from 1000 replications (Felsenstein, 1985).

Almost-complete 16S rRNA gene sequences (1469, 1483 and $1482 \mathrm{bp}$ ) were determined for strains Gsoil $034^{\mathrm{T}}$, Gsoil $060^{\mathrm{T}}$ and $\mathrm{Jip} 13^{\mathrm{T}}$ and subjected to comparative analyses. Phylogenetic analysis based on 16S rRNA gene sequences indicated that these isolates are clustered with $O$. sitiensis AW $-6^{\mathrm{T}}$ within the family Sphingobacteriaceae (Fig. 1). The $16 \mathrm{~S}$ rRNA gene sequence similarity between these isolates and $O$. sitiensis $\mathrm{AW}-6^{\mathrm{T}}$ ranged from 88.5 to $90.1 \%$. The three strains showed 93.9-94.7\% sequence similarity with respect to each other, suggesting that they differ at the species level (Stackebrandt \& Goebel, 1994).
Gram-reaction testing was performed by using the nonstaining method, as described by Buck (1982). Cell morphology was observed at $\times 1000$ magnification with a light microscope (E600; Nikon) using cells grown for 3 days at $30{ }^{\circ} \mathrm{C}$ on R2A agar. Catalase activity was determined from bubble production in $3 \%(\mathrm{v} / \mathrm{v}) \mathrm{H}_{2} \mathrm{O}_{2}$ and oxidase activity was determined using $1 \%(\mathrm{w} / \mathrm{v})$ tetramethyl-p-phenylenediamine. Carbon-source utilization and enzyme activities were tested by using API 20NE, API ID 32GN and API ZYM test kits (bioMérieux). Growth at different temperatures (4,

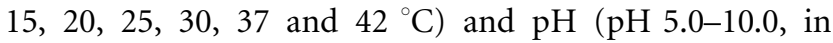
increments of $0.5 \mathrm{pH}$ units) was assessed after 5 days incubation. Salt tolerance was tested on R2A agar supplemented with $1-10 \%(\mathrm{w} / \mathrm{v}) \mathrm{NaCl}$ after 5 days incubation. Growth on nutrient agar, trypticase soy agar and MacConkey agar was also evaluated, at $30{ }^{\circ} \mathrm{C}$.

Morphological observation of strains Gsoil $034^{\mathrm{T}}$, Gsoil $060^{\mathrm{T}}$ and Jip $13^{\mathrm{T}}$ grown on R2A agar plates for 5 days showed that the cells were similar to each other, i.e. all were non-motile rods, $0.6-0.9 \mu \mathrm{m}$ wide and $0.9-1.8 \mu \mathrm{m}$ long. Colonies of the three strains grown on R2A agar were also similar to each other, i.e. smooth, circular, convex, opaque, yellowish and $1.0-2.0 \mathrm{~mm}$ in diameter. All three strains grew on nutrient agar and trypticase soy agar but none grew on MacConkey agar. Strains Gsoil $034^{\mathrm{T}}$ and Gsoil $060^{\mathrm{T}}$ reduced nitrate to nitrite, unlike strain Jip $13^{\mathrm{T}}$. Other physiological characteristics of strains Gsoil $034^{\mathrm{T}}$, Gsoil $060^{\mathrm{T}}$ and $\mathrm{Jip} 13^{\mathrm{T}}$ are summarized in the species descriptions. Phenotypic characteristics that serve to differentiate these strains from their closest phylogenetic relatives are listed in Table 1.

To measure the $\mathrm{G}+\mathrm{C}$ content of the chromosomal DNA, genomic DNA from the novel strains was extracted and

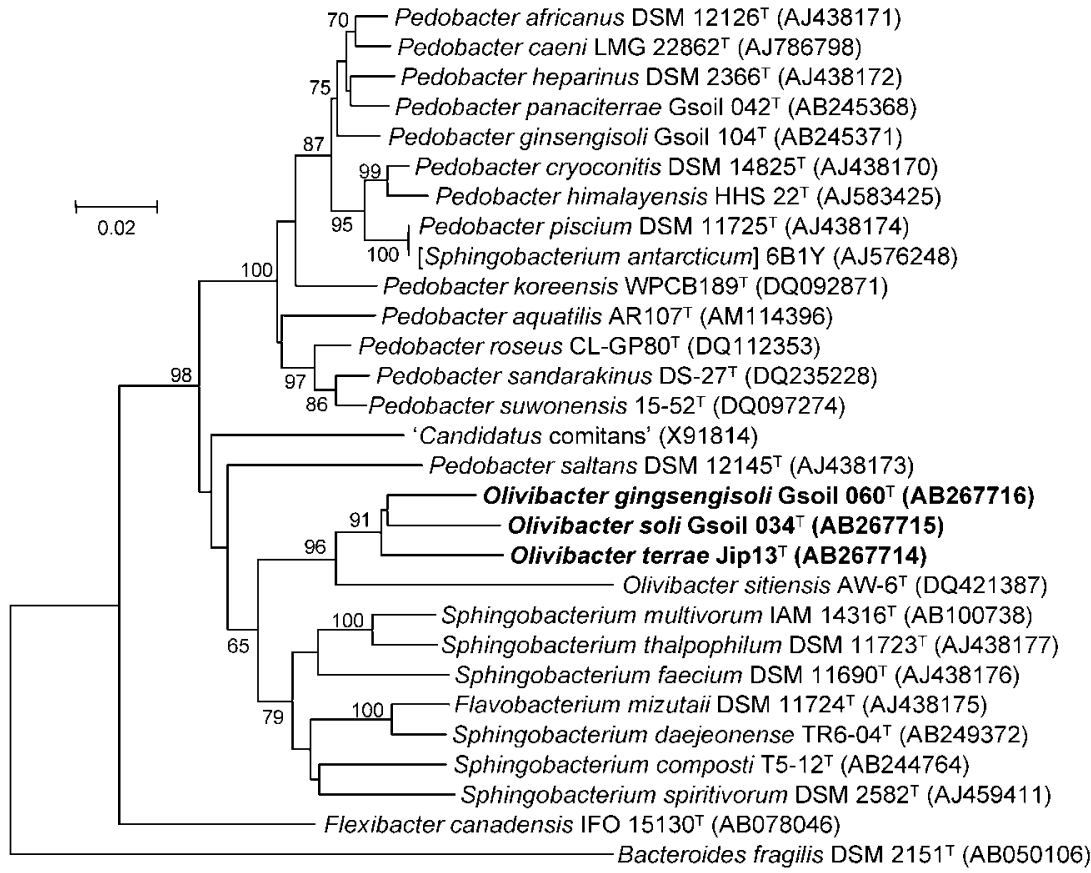

Fig. 1. Rooted phylogenetic tree, based on 16S rRNA gene sequences, for strains Gsoil $034^{\top}$, Gsoil $060^{\top}$ and $\mathrm{Jip}_{13}{ }^{\top}$ and related taxa in the family Sphingobacteriaceae. The tree was constructed using the neighbour-joining method (Saitou \& Nei, 1987) with a Kimura two-parameter distance matrix (Kimura, 1983) and pairwise deletion. Bootstrap values (expressed as percentages of 1000 replications) greater than $60 \%$ are shown at branch points. Bar, 2 substitutions per 100 nucleotide positions. 
Table 1. Comparison of the phenotypic characteristics of strains Gsoil $034^{\top}$, Gsoil $060^{\top}$ and Jip $13^{\top}$ and O. sitiensis AW- ${ }^{\top}$

Data for O. sitiensis AW $-6^{\mathrm{T}}$ were taken from Ntougias et al. (2007). All strains were positive for catalase and for assimilation of sucrose and glucose. All were negative for Gram stain, sporulation and assimilation of acetate, citrate, serine and tryptophan.

\begin{tabular}{|lcccc|}
\hline Characteristic & Gsoil 034 $^{\mathbf{T}}$ & Gsoil 060 $^{\mathbf{T}}$ & Jip13 $^{\mathbf{T}}$ & O. sitiensis AW-6 $^{\mathbf{T}}$ \\
\hline Growth at $42{ }^{\circ} \mathrm{C}$ & - & - & - & + \\
Growth with $4 \% \mathrm{NaCl}$ & + & + & + & - \\
Oxidase activity & + & - & + & + \\
Assimilation of: & - & + & + & - \\
$\quad$ Mannitol & - & + & - & - \\
Inositol & - & - & - & + \\
L-Histidine & + & + & + & + \\
Maltose & - & - & - & + \\
Sorbitol & 39.2 & 43.6 & 40.6 & 45.6 \\
DNA G+C content (mol\%) & & & & \\
\hline
\end{tabular}

purified, as described by Moore \& Dowhan (1995), enzymically degraded into nucleosides and then determined as described by Mesbah et al. (1989), using reversedphase HPLC. Isoprenoid quinones were extracted with chloroform/methanol $(2: 1, \mathrm{v} / \mathrm{v})$, evaporated under vacuum conditions and then re-extracted in $n$-hexane/ water $(1: 1, \mathrm{v} / \mathrm{v})$. The crude $\mathrm{n}$-hexane-quinone solution was purified using Sep-Pak Vac cartridges silica (Waters) and subsequently analysed by HPLC as described previously (Hiraishi et al., 1996). Cellular fatty acid profiles were determined for strains grown on one-tenth-strength trypticase soy agar (Difco) for 3 days. The cellular fatty acids were saponified, methylated and extracted according to the protocol of the Sherlock Microbial Identification System (MIDI). The fatty acids analysed by gas chromatography (6890; Hewlett Packard) were identified using the Microbial Identification software package (Sasser, 1990).

The DNA G + C contents of strains Gsoil $034^{\mathrm{T}}$, Gsoil $060^{\mathrm{T}}$ and Jip $13^{\mathrm{T}}$ were $39.2,43.6$ and $40.6 \mathrm{~mol} \%$, respectively. The major respiratory quinone was MK-7. As shown in Table 2, the major fatty acids in all three strains were summed feature 4 (comprising $\mathrm{C}_{16: 1} \omega 7 c$ and/or iso- $\mathrm{C}_{15: 0}$ $2-\mathrm{OH})$, iso- $\mathrm{C}_{15: 0}$ and iso- $\mathrm{C}_{17: 0} 3-\mathrm{OH}$, which is consistent with the pattern for $O$. sitiensis. However, some qualitative and quantitative differences in the fatty acid composition served to distinguish these three strains from each other and also from O. sitiensis (Table 2).

As the 16S rRNA gene sequence difference used as the threshold for defining a novel genomic species (Stackebrandt \& Goebel, 1994) is $3 \%$, the sequence similarities (88.5-90.1\%) for the three strains with respect to $O$. sitiensis seem somewhat low for clustering together within the same genus. However, few genus-specific characteristics, which are mainly defined by chemotaxonomic data (predominant isoprenoid quinone, fatty acid profile and DNA G + C content), were found in this study. Likewise, sequence similarity values for Sphingobacterium species and Pedobacter species are also relatively low: the lowest sequence similarity value, between the type strains of Sphingobacterium spiritivorum and Sphingobacterium thalpophilum, is only $90.8 \%$, while the level of similarity between the type strains of Pedobacter himalayensis and Pedobacter sandarakinus is $92.3 \%$. Therefore, on the basis of the data and observations described above, it is appropriate to conclude that strains Gsoil $034^{\mathrm{T}}$, Gsoil $060^{\mathrm{T}}$ and Jip $13^{\mathrm{T}}$ should be assigned to the genus Olivibacter as the type strains of three novel species, for which the names Olivibacter soli sp. nov., Olivibacter ginsengisoli sp. nov. and Olivibacter terrae sp. nov., respectively, are proposed.

\section{Description of Olivibacter soli sp. nov.}

Olivibacter soli (so'li. L. gen. n. soli of the soil).

Cells are $0.6-0.8 \times 1.5-1.8 \mu \mathrm{m}$ in size. Colonies grown on R2A agar plates are smooth, circular, convex, nonluminescent, opaque and yellowish in colour within 5 days at $30{ }^{\circ} \mathrm{C}$. Growth is observed at temperatures of $15-37{ }^{\circ} \mathrm{C}$, at $\mathrm{pH} 6.0-8.0$ and with $0-4 \%(\mathrm{w} / \mathrm{v}) \mathrm{NaCl}$. The optimal growth temperature and $\mathrm{pH}$ are $30{ }^{\circ} \mathrm{C}$ and $\mathrm{pH}$ 6.5-7.5. $\mathrm{N}$ Acetyl-D-glucosamine, L-alanine, arabinose, L-fucose, glycogen, gluconate, D-mannose, melibiose, rhamnose and Dribose are assimilated. Positive for hydrolysis of aesculin and gelatin and for $N$-acetyl- $\beta$-glucosaminidase, acid phosphatase, alkaline phosphatase, arginine dihydrolase, cystine arylamidase, $\alpha$-fucosidase, $\alpha$-glucosidase, $\beta$-glucosidase, leucine arylamidase, urease and valine arylamidase and glucose fermentation. Negative reactions are observed for esterase (C4), esterase lipase (C8), lipase (C14), naphthol-AS-BI-phosphohydrolase, $\alpha$-galactosidase, $\beta$ galactosidase, $\beta$-glucuronidase and $\alpha$-mannosidase and for assimilation of adipate, caprate, 3-hydroxybenzoate, 4-hydroxybenzoate, 3-hydroxybutyrate, itaconate, 2-ketogluconate, 5-ketogluconate, lactate, malate, malonate, phenylacetate, L-proline, propionate, salicin, suberate and 
Table 2. Fatty acid profiles of strains Gsoil $034^{\top}$, Gsoil $060^{\top}$ and $\mathrm{Jip}_{13^{\top}}$ and $\mathrm{O}$. sitiensis $\mathrm{AW}-6^{\top}$

Data for O. sitiensis AW- $6^{\mathrm{T}}$ were taken from Ntougias et al. (2007). Values are percentages of total fatty acids; - , not detected.

\begin{tabular}{|c|c|c|c|c|}
\hline Fatty acid & Gsoil $034^{\mathrm{T}}$ & Gsoil $060^{\mathrm{T}}$ & Jip13 ${ }^{\mathrm{T}}$ & O. sitiensis AW- $6^{\mathrm{T}}$ \\
\hline \multicolumn{5}{|l|}{ Saturated } \\
\hline $\mathrm{C}_{14: 0}$ & - & - & 2.0 & 0.5 \\
\hline $\mathrm{C}_{16: 0}$ & 5.7 & 10.4 & 7.7 & 5.5 \\
\hline $\mathrm{C}_{18: 0}$ & 1.3 & 1.5 & - & - \\
\hline \multicolumn{5}{|l|}{ Unsaturated } \\
\hline $\mathrm{C}_{16: 1} \omega 5 c$ & 1.3 & - & - & 1.3 \\
\hline \multicolumn{5}{|l|}{ Branched-chain } \\
\hline iso- $\mathrm{C}_{15: 0}$ & 32.5 & 33.6 & 35.9 & 29.3 \\
\hline iso- $\mathrm{C}_{15: 0} 3-\mathrm{OH}$ & 2.2 & 3.3 & 2.6 & 1.9 \\
\hline anteiso- $\mathrm{C}_{15: 1}$ & 1.1 & - & - & - \\
\hline iso- $\mathrm{C}_{15: 1} \mathrm{~F}$ & - & - & - & 0.3 \\
\hline iso- $\mathrm{C}_{17: 0}$ & - & - & 0.8 & 0.4 \\
\hline iso- $\mathrm{C}_{17: 0} 3-\mathrm{OH}$ & 12.1 & 12.4 & 11.5 & 11.2 \\
\hline iso- $\mathrm{C}_{17: 1} \omega 9 c$ & 1.5 & 0.9 & 1.2 & 2.0 \\
\hline anteiso- $\mathrm{C}_{17: 1} \mathrm{~B}$ and/or iso- $\mathrm{C}_{17: 1} \mathrm{I}$ & - & - & - & 0.5 \\
\hline \multicolumn{5}{|l|}{ Hydroxy } \\
\hline $\mathrm{C}_{16: 0} 2-\mathrm{OH}$ & 1.8 & 2.4 & 2.6 & 0.9 \\
\hline $\mathrm{C}_{16: 0} 3-\mathrm{OH}$ & 1.4 & 2.0 & 1.1 & 0.7 \\
\hline $\mathrm{C}_{16: 1} 2-\mathrm{OH}$ & - & - & - & 0.6 \\
\hline \multicolumn{5}{|l|}{ Unknown* } \\
\hline ECL 13.565 & - & - & - & 0.9 \\
\hline ECL 13.961 & 1.2 & 2.1 & - & - \\
\hline ECL 16.582 & - & - & - & 1.1 \\
\hline Summed feature $4 \dagger$ & 37.3 & 31.6 & 34.7 & 43.2 \\
\hline
\end{tabular}

${ }^{\star}$ Unknown fatty acids have no name listed in the peak library file of the MIDI system and therefore cannot be identified. ECL, Equivalent chain-length.

$\dagger$ Summed feature 4 comprises iso- $\mathrm{C}_{15: 0} 2-\mathrm{OH}$ and/or $\mathrm{C}_{16: 1} \omega 7 c$.

valerate. The DNA $\mathrm{G}+\mathrm{C}$ content of the type strain is $39.2 \mathrm{~mol} \%$.

The type strain, Gsoil $034^{\mathrm{T}}\left(=\mathrm{KCTC} 12645^{\mathrm{T}}=\mathrm{LMG}\right.$ $23492^{\mathrm{T}}$ ), was isolated from soil from a ginseng field in Pocheon Province, South Korea.

\section{Description of Olivibacter ginsengisoli sp. nov.}

Olivibacter ginsengisoli (gin.seng.i.so'li. N.L. n. ginsengum ginseng; L. n. solum soil; N.L. gen. n. ginsengisoli of soil of a ginseng field).

Cells are $0.7-0.9 \times 1.2-1.6 \mu \mathrm{m}$. Colonies grown on R2A agar plates are smooth, circular, convex, non-luminescent, opaque and yellowish in colour within 5 days at $30{ }^{\circ} \mathrm{C}$. Growth is observed at temperatures of $15-30{ }^{\circ} \mathrm{C}$, at pH 6.0-8.0 and with $0-4 \%(w / v) ~ N a C l$. The optimal growth temperature and $\mathrm{pH}$ are $30{ }^{\circ} \mathrm{C}$ and $\mathrm{pH}$ 6.8-7.5. $\mathrm{N}$ Acetyl-D-glucosamine, arabinose, gluconate, D-mannose, melibiose, rhamnose and salicin are assimilated. Positive for hydrolysis of aesculin and gelatin and $N$-acetyl- $\beta$ glucosaminidase, acid phosphatase, alkaline phosphatase, arginine dihydrolase, esterase (C4), $\alpha$-galactosidase, $\alpha$-glucosidase, $\beta$-glucosidase, leucine arylamidase, urease and valine arylamidase and for glucose fermentation. Negative reactions are observed for cystine arylamidase, esterase lipase (C8), $\alpha$-fucosidase, lipase (C14), naphtholAS-BI-phosphohydrolase, $\beta$-galactosidase, $\beta$-glucuronidase and $\alpha$-mannosidase and for assimilation of adipate, Lalanine, caprate, L-fucose, glycogen, 3-hydroxybenzoate, 4-hydroxybenzoate, 3-hydroxybutyrate, itaconate, 2-ketogluconate, 5-ketogluconate, lactate, malate, malonate, phenylacetate, L-proline, propionate, D-ribose, suberate and valerate. The DNA G $+C$ content of the type strain is $43.6 \mathrm{~mol} \%$.

The type strain, Gsoil $060^{\mathrm{T}}\left(=\right.$ KCTC $12646^{\mathrm{T}}=\mathrm{LMG}$ $23491^{\mathrm{T}}$ ), was isolated from soil from a ginseng field in Pocheon Province, South Korea.

\section{Description of Olivibacter terrae sp. nov.}

Olivibacter terrae (ter'rae. L. gen. n. terrae of the earth).

Cells are $0.6-0.8 \times 0.9-1.3 \mu \mathrm{m}$. Colonies grown on R2A agar plates are smooth, circular, convex, non-luminescent, opaque and yellowish in colour within 5 days at $30{ }^{\circ} \mathrm{C}$. 
Growth is observed at temperatures of $15-30{ }^{\circ} \mathrm{C}$, at $\mathrm{pH} 6.0-8.0$ and with $0-4 \%(\mathrm{w} / \mathrm{v}) \mathrm{NaCl}$. The optimal growth temperature and $\mathrm{pH}$ are $30{ }^{\circ} \mathrm{C}$ and $\mathrm{pH}$ 7.0. $\mathrm{N}$ Acetyl-D-glucosamine, arabinose, glycogen, gluconate, $\mathrm{D}$ mannose, rhamnose and D-ribose are assimilated. Positive for hydrolysis of aesculin and gelatin and for $N$-acetyl- $\beta$ glucosaminidase, acid phosphatase, alkaline phosphatase, arginine dihydrolase, cystine arylamidase, esterase (C4), esterase lipase (C8), $\alpha$-galactosidase, $\alpha$-glucosidase, $\beta$ glucosidase, $\beta$-glucuronidase, leucine arylamidase, urease and valine arylamidase and glucose fermentation. Negative reactions are observed for $\alpha$-fucosidase, $\beta$-galactosidase, lipase (C14), naphthol-AS-BI-phosphohydrolase and $\alpha$ mannosidase and for assimilation of adipate, L-alanine, caprate, L-fucose, 3-hydroxybenzoate, 4-hydroxybenzoate, 3-hydroxybutyrate, itaconate, 2-ketogluconate, 5-ketogluconate, lactate, malate, malonate, melibiose, phenylacetate, L-proline, propionate, salicin, suberate and valerate. The DNA G $+\mathrm{C}$ content of the type strain is $40.6 \mathrm{~mol} \%$.

The type strain, Jip $13^{\mathrm{T}}$ (=KCTC $12644^{\mathrm{T}}=\mathrm{LMG} 23494^{\mathrm{T}}$ ), was isolated from compost, composed of cow dung and rice straw, collected in Chungwon Province, South Korea.

\section{Acknowledgements}

This work was supported by the 21C Frontier Microbial Genomics and Application Center Program, Ministry of Science and Technology (grant MG05-0101-4-0), Republic of Korea.

\section{References}

Buck, J. D. (1982). Nonstaining (KOH) method for determination of Gram reactions of marine bacteria. Appl Environ Microbiol 44, 992993.

Felsenstein, J. (1985). Confidence limits on phylogenies: an approach using the bootstrap. Evolution 39, 783-791.

Fitch, W. M. (1971). Toward defining the course of evolution: minimum change for a specific tree topology. Syst Zool 20, 406-416.

Hall, T. A. (1999). BioEdit: a user-friendly biological sequence alignment editor and analysis program for Windows 95/98/NT. Nucleic Acids Symp Ser 41, 95-98.

Hiraishi, A., Ueda, Y., Ishihara, J. \& Mori, T. (1996). Comparative lipoquinone analysis of influent sewage and activated sludge by high-performance liquid chromatography and photodiode array detection. J Gen Appl Microbiol 42, 457-469.

Im, W.-T., Kang, M.-S., Park, H.-Y., Kim, M.-K. \& Lee, S.-T. (2003). Culturable bacterial strain's diversity of environmental samples. In Proceedings of the International Meeting of the Federation of Korean Microbiological Societies, abstract B4023, p. 165. Seoul: Federation of Korean Microbiological Societies.

Im, W.-T., Jung, H.-M., Cui, Y.-S., Liu, Q.-M., Zhang, S.-L. \& Lee, S.-T. (2005). Cultivation of the three hundreds of bacterial species from soil of a ginseng field and mining the novel lineage bacteria. In Proceedings of the International Meeting of the Federation of Korean Microbiological Societies, abstract A035, p. 169. Seoul: Federation of Korean Microbiological Societies.

Kim, M. K., Im, W.-T., Ohta, H., Lee, M. \& Lee, S.-T. (2005). Sphingopyxis granuli sp. nov., a $\beta$-glucosidase producing bacterium in the family Sphingomonadaceae in $\alpha-4$ subclass of the Proteobacteria. J Microbiol 43, 152-157.

Kimura, M. (1983). The Neutral Theory of Molecular Evolution. Cambridge: Cambridge University Press.

Kumar, S., Tamura, K. \& Nei, M. (2004). MEGA3: integrated software for molecular evolutionary genetics analysis and sequence alignment. Brief Bioinform 5, 150-163.

Mesbah, M., Premachandran, U. \& Whitman, W. B. (1989). Precise measurement of the $\mathrm{G}+\mathrm{C}$ content of deoxyribonucleic acid by highperformance liquid chromatography. Int J Syst Bacteriol 39, 159-167.

Moore, D. D. \& Dowhan, D. (1995). Preparation and analysis of DNA. In Current Protocols in Molecular Biology, pp. 2-11. Edited by F. W. Ausubel, R. Brent, R. E. Kingston, D. D. Moore, J. G. Seidman, J. A. Smith \& K. Struhl. New York: Wiley.

Ntougias, S., Fasseas, C. \& Zervakis, G. I. (2007). Olivibacter sitiensis gen. nov., sp. nov., isolated from alkaline olive-oil mill wastes in the region of Sitia, Crete. Int J Syst Evol Microbiol 57, 398-404.

Saitou, N. \& Nei, M. (1987). The neighbor-joining method: a new method for reconstructing phylogenetic trees. Mol Biol Evol 4, 406-425.

Sasser, M. (1990). Identification of bacteria by gas chromatography of cellular fatty acids, MIDI Technical Note 101. Newark, DE: MIDI Inc.

Stackebrandt, E. \& Goebel, B. M. (1994). Taxonomic note: a place for DNA-DNA reassociation and $16 \mathrm{~S}$ rRNA sequence analysis in the present species definition in bacteriology. Int J Syst Bacteriol 44, 846-849.

Thompson, J. D., Gibson, T. J., Plewniak, F., Jeanmougin, F. \& Higgins, D. G. (1997). The CLUSTAL_X windows interface: flexible strategies for multiple sequence alignment aided by quality analysis tools. Nucleic Acids Res 25, 4876-4882. 